University of Nebraska - Lincoln

DigitalCommons@University of Nebraska - Lincoln

Agronomy \& Horticulture -- Faculty Publications

Agronomy and Horticulture Department

10-1931

\title{
Who's Who Among The Prairie Grasses
}

J. E. Weaver

University of Nebraska-Lincoln

Follow this and additional works at: https://digitalcommons.unl.edu/agronomyfacpub

Part of the Plant Sciences Commons

Weaver, J. E., "Who's Who Among The Prairie Grasses" (1931). Agronomy \& Horticulture -- Faculty Publications. 463.

https://digitalcommons.unl.edu/agronomyfacpub/463

This Article is brought to you for free and open access by the Agronomy and Horticulture Department at DigitalCommons@University of Nebraska - Lincoln. It has been accepted for inclusion in Agronomy \& Horticulture -Faculty Publications by an authorized administrator of DigitalCommons@University of Nebraska - Lincoln. 


\section{ECOLOGY}

\begin{tabular}{lll}
\hline \hline Vol. XII & OCTOBER, r93I & No. 4 \\
\hline \hline
\end{tabular}

WHO'S WHO AMONG THE PRAIRIE GRASSES ${ }^{1}$

J. E. Weaver

University of Ncbraska

For many years I have lived on the prairie, where I became familiar with the grasses. Each spring I have been delighted with their renewal of growth -in watching the brown landscape of rolling hills become carpeted with green. Year after year, with the progress of the season, I have seen the changing aspects, which, with the coming of autumn, end in the wonderful coloration of the prairie grasses. But the prairie as a whole has seemed a somewhat elusive thing, difficult to visualize, not easy to describe, indefinite and extremely variable in its composition. This vagueness of understanding, I believe, has been shared by other students of prairie. A careful survey of the literature reveals scarcely a single contribution that gives a clear idea of the structure of the vegetation, i.e., what the dominant species are and why they are dominant; what patterns or types of grassland occur in prairie; where they occur; their relative importance; and to what degree the various species intermingle to form them.

\section{Tall-Grass Area Studied}

I finally decided that the real difficulty, in my own case at least, was a lack of definite information. Perhaps I did not know the grasses at all but was merely on speaking terms with them. A central area of tall-grasses right in the heart of the prairie was accordingly selected for study. It was large enough to be thoroughly representative, but not so extensive as to defeat the plan of intensive investigation. It included the tall-grass prairies of the western one-third of Iowa and those of Nebraska. On the south it extended into Missouri and Kansas to the Kansas River, and northward into southwestern Minnesota and southern South Dakota. The plan included a study of Ioo typical prairie areas well scattered throughout. So far about 80 have been investigated. Supplementing other studies, there are now several hundred quadrats to determine the exact percentage composition.

${ }^{1}$ Address of the retiring President of the Ecological Society of America, presented at the annual dinner at Cleveland, Ohio, January, i93I.

[Ecology, Vol. XII, No. 3 (pp. 455-621) was issued July 23, 1931] 


\section{Representative Tall-Grass Areas Still Remaining}

After careful searching, it was gratifying to learn that representative areas of grassland are still to be found. They sometimes occupy the rougher lands but frequently occur on level or slightly rolling ground. Such areas, varying in size from 40 acres to a square mile, have been found here and there throughout, and in many places native grassland is still abundant. Where the land has been kept as Indian reservations, extensive tracts of prairie still remain - as my good friend in Kansas expressed it-just as God left them.

All of the prairie areas are disturbed, usually, only by late annual mowing. To what extent, if any, they have been modified from the original grassland (which was both grazed and burned) can not be determined. But their resistance to invaders, even when the area is entirely surrounded by them, shows in an impressive manner their high degree of stabilization and their wonderful adjustment to the environment.

That the prairies are making their last stand against the invader-mancan not be overemphasized. Detached areas are even now often separated by many miles. Every year some of these scattered relict outposts are yielding before the plow or being destroyed by intensive grazing.

After considerable study, it was found that the complex, intricate, and apparently endlessly variable cover of grassland resolved itself into a few distinct types. Further studies revealed that each type was characterized by only one or a few really important grasses. While there is variation within the type or pattern, and considerable alternating and overlapping, yet once the types are recognized the whole prairie problem is greatly clarified.

\section{LOWLAND TyPES}

The big bluestem type is the most representative, most extensive, and most important of those found on the lowlands. It is characterized by the single species, Andropogon furcatus. This species is one of the two most important dominants of prairie. Together with little bluestem (Andropogon scoparius) of uplands, it constitutes fully 70 per cent of the entire grassland cover. It is more mesic than the little blue stem and is best developed on lower slopes and well aerated lowlands. It is not confined to them, however, but is represented in practically every square meter of the little bluestem type of uplands, where it constitutes, on an average, 25 per cent of the plant cover. It does not thrive in soil that is frequently saturated, and under such conditions it gives way to slough grass (Spartina michanxiana). Almost pure stands occur over extensive areas, except for a small admixture of bluegrass (Poa pratensis), Indian grass (Sorghastrum nutans), and a few nongrassy species. The actual plant cover within this type averages 80 per cent big bluestem; it frequently runs as high as 90 per cent, and rarely falls below 60. 
The causes of dominance of big bluestem are found in its rapid growth, dense, sod-forming habit, and great stature, as well as its tolerance of shade. Seedlings develop rapidly. A height of 12 to 18 inches and a root depth of 2 to 4 feet may be reached in a single summer. The tillering habit is pronounced. Seven or 8 weeks after germination, tillers begin to appear, and soon the seedling develops a small tuft or bunch. Rhizomes are also quickly produced, and the area occupied by both shoots and roots is thus greatly increased. Both seedlings and mature plants are very tolerant of shade. The leaves remain green and manufacture carbohydrates under light intensities of only 5 to Io per cent.

As a result of the rhizome habit, Andropogon furcatus typically develops a characteristic sod. The individual stems are usually spaced more than a centimeter apart. Even in the densest clumps they average less than one per square centimeter. Moreover, between the mats of sod there is much unoccupied soil. The total ground cover in this type rarely exceeds 25 per cent. Notwithstanding this open spacing, the foliage is so dense and the light so greatly reduced that invasion is extremely difficult. It is more or less successfully accomplished by bluegrass, and easily so as a result of annual mowing. Andropogon, being a genus of southern extraction, renews growth rather late in spring-usually about mid-April, and several weeks after the appearance of Poa. The bluegrass may even blossom before it is much shaded by its big competitor. Poa was found in the big bluestem type nearly 80 per cent of the time. It formed from I to I 5 per cent of the total ground cover. But on the upland where the tall stems of Andropogon furcatus are often too few to greatly reduce the light, invasion is more readily accomplished. Quite in contrast is the very dense growth of Andropogon scoparius; the area actually covered by this species is rarely invaded.

The development of the shoots of the big bluestem in the perennial sod is rapid. By the first of June the average height is normally about I 2 inches, and by July, I 8 to 24 inches. The flower stalks begin to appear above the general level of the foliage early in July, but anthesis does not reach its maximum until late August or in September. On dry slopes flowering may not occur except during very favorable years. Here flower stalks only 3 feet tall and with a single inflorescence are not uncommon. But in the lowland, both flower stalks and spikes are extremely abundant and well developed. For example, along the Missouri bottomlands the foliage of this rank grass reaches a height of 3 feet and the flower stalks 8 to ro feet.

What chance has any other grass against such a formidable competitor? The answer is, little or none. Only one other species approaches it as an ecological equivalent, and that is the Indian grass (Sorghastrum nutans). It is, however, of far less importance. This species is most abundant in Kansas, where it may very locally constitute 90 per cent of the vegetation but more usually only 5 to $\mathrm{I}_{5}$. Throughout the region as a whole, Indian grass was found in only one-third of the quadrats. The usual percentage 
was from I to 3, and in many lowlands it was almost absent. It typically occurs in the dense bluestem sod as isolated stems or very small clumps. Its large seeds are remarkably viable, and germination is high. This grass is of approximately the same size as big bluestem, makes the same rapid growth, and is also very tolerant of shade. It thrives in areas occasionally denuded by floods or repeated fires. In fact, its abundance usually indicates disturbance. The weak spot in its life history is its inability to tiller and form rhizomes under competition, and thus to extend its territory. Big bluestem is more prompt and more vigorous in this strategy, and consequently it possesses the land.

A second type of grassland pattern is that dominated by slough grass (Spartina michauxiana). This species is really not a dominant of low prairie but is the final consocies of the hydrosere leading to the prairie proper. It grows typically at the edge of sluggish streams or ponds and in water-logged or wet soil, rarely occurring in moist soils except in dry seasons or as relicts in soils that have been drained.

Its demarcation of soils too wet and consequently too poorly aerated for the growth of maize is clearly shown throughout the prairie. In countless areas the uplands and big-bluestem lowlands have been broken, but the sloughgrass draws and flooded lands have been left intact. They are too wet for cropping, at least in spring, but furnish excellent hay, and very successfully hold the soil against erosion. Vast areas of "first bottom" along the Missouri and its tributaries are covered with Spartina, often in almost pure stands. Towards the mesic side it gives way to big bluestem, usually through a transitional type to be described.

Spartina plays the rôle of a dominant because of its tall growth in dense, pure stands. Light values near the soil surface are often only I to 2 per cent and the shade is equalled only in the densest climax forests. Seedlings grow vigorously in wet, bare areas and to a height of 3 to 4 feet in a single summer. But reproduction, except in such areas, is undoubtedly almost entirely by means of the extensive underground stems. Beneath mature plants the soil is filled with a mat of coarse, woody, very much branched rhizomes. These extend outward 2 to I 5 inches before giving rise to erect shoots. The depth of root penetration is surprising, considering the water relations of the habitat. Depths of 8 to Io feet are commonly found in wet soil. This grass has coarser roots than any of those of the prairie proper.

Although slough grass renews activity rather late, often not until the second week in April, it grows more rapidly than any of the prairie grasses. By the first of June it is frequently in the sixth leaf stage and varies from 2 to over 3 feet in height. Where it shares marginal areas with other grasses it conspicuously overtops them. The general height of leaves at the end of the growing season is 3 to 7 feet, depending upon the water supply. Because of the extensive rhizomes, it always forms a sod. Where best developed, the coarse, woody stems are widely spaced, and the soil surface 
actually occupied is often only I to 3 per cent. In the dense shade 2 or 3 of the basal leaves are usually dead by midsummer, leaving the stems bare to a height of about 8 to I 2 inches. Even in moist soil the flower stalks are 5 to 6 feet tall and in wet areas they often reach 9 to Io. Where an abundant and constant water supply favors the growth of Spartina, other prairie grasses are effectually excluded.

An intermediate lowland type of much less extent than either of the preceding occurs between the big bluestem and the slough grass areas. It is characterized by two species, tall panic grass (Panicum virgatum) and nodding wild rye (Elymus canadensis).

Panicum virgatum is a tall, coarse, sod-forming grass and an important dominant in low, moist soil. It is perhaps the most mesic of prairie grasses as is shown by its abundance in the drier portions of the Spartina consocies, occupying with wild rye and red top (Agrostis alba) areas that are too poorly aerated for the growth of big bluestem. It is rarely found in extensive pure stands, the clumps and areas usually alternating with slough grass, sedge (Carex aulpinoidea), etc. In such mixtures it covers many square miles of poorly drained bottomlands along the Missouri and its tributaries, constituting Io to 30 or more per cent of the vegetation. With wild rye it is almost invariably found as a transition species along ravines and draws whereever big bluestem gives way to slough grass. The transition, whether gradual or abrupt, is characterized by small areas of Panicum in dense, pure stands, by clumps often 3 to 4 feet in diameter, and by an intermingling with the bluestem on its marginal areas. While it may locally constitute 25 per cent of the grass mixture, it often falls to Io per cent, and where Andropogon is well developed, to less than 3 . It is also found in areas of higher water-content at the heads of broad, sloping flats receiving run-off water. The rank growth at the bottom of ravines where it is often 6 feet high, gradually decreases to about 3 feet near the top. Moreover, the dense sod becomes thinner as the grass extends its area into drier lands until only scattered, dwarfed, individual stems occur.

Panicum is of tropical derivation and consequently more important in the south and east portions of the area where the climate is more humid as well as warmer. It is largely replaced northward by Elymus. Seeds of Panicum usually give a low rate of germination, and propagation is undoubtedly largely by rhizomes. The seedlings develop rapidly but are less tolerant of shade than are those of the big bluestem. It renews growth late in spring but owing to an abundance of food in roots and rhizomes it develops rapidly and is often 18 inches tall by the first of May. Because of the lack of basal shoots and the wide spacing between stems, only a small amount of the surface soil is actually occupied. But the foilage is luxuriant, and only the most tolerant of lowland species such as big blustem can grow in the shade of this dominant.

Elymus canadensis is also a tall, coarse grass of about the same stature as Panicum virgatum, and, like it, has a high water requirement. Although of 
wide and regular distribution, it is of minor importance over the prairie as a whole. It is typically a lowland species, reaching its best development in the wet transitional areas between slough grass and big bluestem. It also intermingles more or less with both of these. It forms pure stands only in very small areas. Usually it constitutes a $\mathrm{I}$ to 5 per cent mixture among the other grasses, and exceptionally Io to 15 . Among 300 quadrats in low prairie, this species occurred in only 32 , and it never exceeded 2 per cent in abunclance. On uplands, wild rye is found only where local disturbance has occurred, as about gopher mounds, badger holes, etc. It forms a reliable indicator of increased water-content due to local denudation on upper slopes and ridges. Once in possession, the bunches or clumps may remain many years.

Northward and westward, Elymus becomes more abundant than in the south and east. Here, on level land subject to overflow and too wet for big bluestem, it often covers large tracts and resembles thinly planted fields of barley. Examination shows that the abundance is more apparent than real. Rarely more than 40 to 50 stalks occur per square meter. Since there are few or no basal shoots or leaves it may form only 5 to 8 per cent of the ground cover.

The relatively large seeds of Elymus show a high rate of germination. Unlike most grasses, they germinate well even when covered with soil to a depth of 2 inches. Early in August, a height of 6 to ro inches is attained, and sometimes flower stalks are produced the first season. Tillering begins early, the short rhizomes resulting in the formation of bunches or clumps. Because of its northern extraction, growth is resumed very early in spring, 2 or 3 weeks before that of its competitors. This is distinctly advantageous to this species in its competition for light.

\section{Upland Types}

The most important and most extensive of upland types is that characterized by little bluestem (Andropogon scoparius). Just as big bluestem is the most important dominant of low prairie, so also little bluestem forms the great bulk of the upland grass cover. It easily exceeds in importance all other upland species combined. In the south and east, where moisture is more plentiful, its chief competitor is big bluestem. In the north and west, especially on poor soils and areas with extreme run-off, little bluestem intermingles with needle grass (Stipa spartea) and in places is almost replaced by it.

Little bluestem ordinarily forms an interrupted sod, which is best developed northward. The mats or tufts are so dense that few other species can invade them. Accompanying species grow between the mats. Where the slopes are steep and run-off and erosion great, the bunch habit becomes pronounced. 
On the deep soils of steep loess hills, little bluestem alone frequently constitutes 90 per cent of the vegetational cover; and, over the area as a whole, including level uplands, 50 to 75 per cent. On midslopes and lower hillsides it intermingles with the big bluestem, often on equal terms. On lower lands, the big bluestem and other tall grasses have the decided advantage in securing light, and, if there is sufficient water for a continuous cover of the taller grasses, little bluestem entirely disappears.

The percentage of germination of little bluestem is often low, but the seedlings are vigorous. During the first summer they reach a height of 6 to 8 inches, and tiller profusely. The young roots are fine and extremely well branched. Thus the plant is well fitted to absorb in relatively dry soil. In the absence of competition it may complete its life cycle by producing flower stalks and seeds the first year. But in the prairie, this requires 2 seasons very favorable for growth, and ordinarily 3 or more.

The mature root system consists of a vast network of threadlike roots and masses of finely branched rootlets. Thus the soil beneath the sod mat, and for several inches on all sides of it, is filled with roots to a depth of about 5 feet. Such an absorbing system is wonderfully efficient.

The leafy stems grow compactly in the sod mat. There are often 200 to 300 in a single square decimeter. Many of these are furnished with several tillers each, and all are leafy to the base. Thus there is little room for invasion. The density of the mat varies with the water relation and also with age. On lower slopes the whole sod may consist of closely crowded stems, but on uplands, and especially during dry years, the center may have few stems and the peripheral ones show a much better growth. Deterioration of the clump nearly always occurs first in the older, central part and proceeds toward the periphery.

The size of the sod mats is variable. In favorable situations solid clumps I. 5 by 2 feet in extent may be found. But normally they are smaller, often 6 to 8 inches or less, and the shape is irregular. Often the sod consists of smaller tufts rather closely aggregated so that the overlapping leaves give an apparent cover of 80 to Ioo per cent. Actually the basal cover in any case seldom exceeds 25 per cent. Larger and better filled clumps occur southward, while the best development of the tufted, sod-mat type is found in northern Nebraska and Dakota. The height attained by this species is variable. It ranges from 7 inches on dry hilltops and regions of lowest rainfall to 22 in the warmer, more humid southeast. On moderately low lands, in competition with the taller grasses, heights of 3 feet or more are attained.

Flower stalks begin to appear by the middle of August. These vary in height from I.5 to 2 feet on dry uplands, where blossoming may occur only during exceptionally wet years, to 3 to 4 feet under a more favorable water supply. Flower stalks are usually thickly grouped, and seeds are produced in great abundance. By early winter nearly all have been dislodged 
by the wind, but the old flower stalks persist a long time. The wonderful coloration of the prairie in late autumn is due largely to the drying bluestems.

Of the two other upland patterns, that formed by the needle grass (Stipa spartea) is the most important. This bunch grass is typically an upland species. It is practically of no importance in the Kansas and Missouri portions of the area, but it gradually increases in abundance northward and becomes an important prairie component. Steep, dry ridges and xeric slopes, especially where the soil is thin and perhaps sandy or gravelly, are frequently more or less dominated by Stipa. Such areas alternate with the little bluestem pattern or with that of the drop seed (Sporobolus heterolepis). Its chief associates are June grass (Koeleria cristata) and little bluestem but it is found in various grassy mixtures.

Because of the excellent growth of Stipa on dry banks along roadsides, and its very deceptive appearance as regards abundance, its frequency and importance are easily overstated. Even where the bunches are a foot apart, the widely spreading leaves and gracefully bending stems, which may extend I to 3 feet on all sides of the clump, give the appearance of a thick growth. A study of the composition of the vegetation in which Stipa appears to dominate shows that it really constitutes only i 5 to 35 per cent. Rarely it makes up 50 to 80 per cent of the plant cover, and this only in small areas. In many prairies it is scarcely represented, and usually it forms I to 3 per cent of the vegetation as a whole; but in hilly lands, in the central and northern part of the area, alternes with an abundance of Stipa may cover from onefifth to one-third of extensive uplands. Moreover, it is frequently more or less abundant on flat lands at the heads of draws, and is readily distributed over broad washes on lower slopes that are subject to overflow and deposit during exceptionally heavy rains. Here it is found with big bluestem usually in no great abundance but sometimes dominating local areas.

The large, heavy, long-awned seeds of Stipa germinate normally only after being worked I to 3 inches into the soil. The seedlings make a good growth, and by midsummer the parent culms are often a foot tall and well furnished with tillers. By this time the fine, well branched root system is usually $\mathrm{I} .5$ feet deep and in good contact with the moist subsoil. True to their boreal extraction, year-old Stipa seedlings begin growth in March. They are 3 to 4 inches tall and in the third- or fourth-leaf stage before most other grasses have broken their dormancy. By the second summer the foliage may reach a height of 2 to 3 feet, but the production of flower stalks ordinarily does not occur until the third year. The root system of even mature plants seldom reaches depths beyond 2.5 to 3 feet, but it is exceedingly well fitted for absorption from the upper levels.

The production of tillers and short rhizomes gives rise to more or less circular clumps or bunches; needle grass never forms a sod. The size of the clumps is variable, depending upon conditions for growth; some are only one-fourth inch in diameter, the largest perhaps 5 inches. Wherever Stipa 
is at all abundant, the ground cover is very open, and the greater the apparent density of the species the more bare soil. Often only 5 to 7 per cent of the soil surface is occupied. Small tufts may have only a single flower stalk, but large clumps often produce 18 or more. By June Io, the twisting awns indicate the ripening of the seeds, and by the first week in July the seeds have fallen and are widely scattered by the wind. The excellent method of planting the seed compensates the small numbers, usually only a dozen or two per flower stalk.

The bases of the long, spreading clusters of rosette-like leaves often remain green all winter, and growth is resumed with the first warm days. As a result of its early growth it avoids excessive competition.

Stipa, accompanied by Koeleria, represents an earlier stage in development than do the andropogons.

Koeleria cristata is also a bunch grass, but of smaller stature than any of the preceding. Like Stipa, it is of boreal origin and is more abundant in the northern part of the area. It shows a decided preference for dry uplands, and is typically associated with needle grass, drop seed, and little bluestem. Not infrequently, however, it occurs also on lower mid-slopes, and, in lesser abundance, on well-drained lowlands.

In many prairies, especially southward, this species may be scarcely if at all represented, but it more usually forms I to 3 per cent of the cover, at least locally. An abundance greater than 5 to Io per cent is rarely found except in disturbed places.

A minor and final upland prairie pattern is exhibited by Sporobolus heterolepis. This species of drop seed is distinctly a bunch former. Notwithstanding its wide distribution, it is not found in many of the prairies. It is always most abundant on the driest uplands where it may dominate local areas, forming 80 or more per cent of the vegetational cover. More usually it occurs as scattered bunches intermingling with needle grass and little bluestem where it may constitute anywhere from I to 20 per cent of the cover.

The bunches are usually about 5 inches in diameter, but larger ones up to $\mathrm{I} 8$ inches occur. They deteriorate as a result of the death of the central part, and often break up into numerous tufts which give the appearance of a loose, open, discontinuous sod. The stems are so densely aggregated that no other species can invade the tufts. The plant early renews growth, and the foliage reaches a height of Io to 18 inches. The long, attenuated leaves do not stand erect but curve gracefully, so that the top of the bunch much exceeds the basal area. For example, in a typical area where this species constituted all but 2 per cent of the vegetation, the apparent cover was about 90 per cent, yet less than Io per cent of the soil surface was occupied. Underground, however, the whole soil mass was preempted by roots. Once in possession, it keeps its holdings against all invaders for long periods of time. 


\section{Sum MARY}

We may summarize by saying that the bluestems are the aristocrats of the prairie. Their holdings are by far the most extensive. Andropogon furcatus has almost complete possession of the best lowland soils, sharing them only in a very small way with Sorghastrum nutans. It keeps out invaders, except a limited amount of Poa pratensis, by its clense shade.

Andropogon scoparius possesses the uplands. It holds them against invasion by its dense aggregation into sod mats, and appropriates most of the water-supply by virtue of its wonderfully efficient root system.

On the lowlands, only the less desirable, poorly aerated soils are held by Spartina michauxiana and the transition to well aerated ones by Panicum virgatum and Elymus canadensis. On the uplands the thinner, poorer soils, as a rule, are possessed by Stipa spartca or Sporobolus hetcrolepis, and even here Andropogon scoparius contests for possession. Kocleria cristata associates with all of these land-owners but rarely has holdings of its own.

Hence, in a "Who's Who among the Prairie Grasses" Andropogon furcatus and Andropogon scoparius would be found in bold type and their accomplishments would cover several pages. Ordinary type and a single page would be sufficient for Spartina and Stipa, while Panicum, Elymus, and Sporobolus would probably each receive but a single paragraph. The names of Poa, Sorghastrum, and Koeleria would correspondingly be in 6 point. Few other grasses have sufficient importance to be included. 